\title{
Penerapan Metodologi Penafsiran Al-Qur'an dalam Dakwah
}

\author{
Abdul Rauf Bin Rimi ${ }^{1}$, Eni Zulaiha² \\ 1,2Pascasarjana Ilmu Al-Qur'an dan Tafsir UIN Sunan Gunung Djati Bandung \\ Email: ibnuhajirimi92@Gmail.Com¹,Enizulaiha@uinsgdac.id²
}

\begin{abstract}
It is no longer doubtful that the descent of the Qur'an to the Prophet Muhammad through the angel of Allah is jibrail, and then spread to humans for the purpose of their guidance and reference. As for the sacred kalam that leads to the study carried out in it with the appropriate method. This is caused because to avoid the validity of the meaning either from the context of the verse or its meaning. Because the sacred kalam is global in nature, it requires a detailed explanation of the meaning contained therein. So the birth of an effort to understand it. Which is a number of aspects of the method of interpretation which consists of the ijmali method, the tahlili method, the muqaran method and also the maudhui method. The requirements for becoming a commentator consisting of fifteen requirements to become commentators and to become preachers are eight conditions. If the requirements are met, then complete the character of a priest in the field of religion.
\end{abstract}

Keyword: Al-Quran, Da'wah, Methodology

\begin{abstract}
ABSTRAK
Tidak diragui lagi bahwa turunnya Al-Qur'an kepada Nabi Muhammad saw melalui malaikat Allah swt yaitu jibrail, dan kemudian disebarkan kepada manusia dengan tujuan panduan dan rujukan mereka. Adapun kalam suci itu memacukan kearah supaya di lakukan kajian di dalamnya dengan metode yang sesuai. Ini di sebabkan karena untuk mengelakkan berlakunya salah makna baik dari konteks ayat ataupun maknanya. Kerana kalam suci tersebut sifatnya adalah global yang mana ia memerlukan kepada penjelasan yang detail terhadap sesuatu makna yang terkandung di dalamnya. Maka lahirnya usaha untuk memahaminya. Yang mana ia merupakan berberapa aspek dalam metode penafsiran yang mana ianya terdiri daripada metode ijmali, medote tahlili, metode muqaran dan juga metode maudhui. Adapun persyaratan dalam menjadi mufasir yang terdiri daripada lima belas syarat untuk menjadi mufassir dan untuk menjadi da'I adalah lapan syarat. Apabila persyaratan dipenuhi, maka lengkaplah karekter seorang imuwan dalam bidang agama.
\end{abstract}

Kata Kunci: Al-Quran, Dakwah, Metodologi

\section{PENDAHULUAN}

Turunnya satu agama yang mana agama tersebut merupakan agama pelengkap dan sempurna bagi semua umat manusia yaitu agama Islam (Bagir, 2017). Agama yang terakhir yang dibawa oleh nabi junjungan yaitu Nabi Muhammad saw. Kitab suci yang terakhir yang bawa baginda adalah Al-Qur'an. Turunya Al-Qur'an tersebut tidak lain adalah dengan tujuan untuk mengimbangi semua aspek kehidupan manusia baik Islam maupun sebaliknya. Dalam arti kata lain adalah kefleksibalitas dengan pemaknaan dengan penjelasan yang telah dibawa oleh Baginda nabi Muhammad saw. dan kemudian diterangkan lagi kepada sahabat dan seterusnya. Keoriginalitas terhadap Al-Qur'an dipelihara sehinggalah berlakunya hari kiamat (Ghani, 2016).

* Copyright (c) 2020 Abdul Rauf Bin Rimi dan Eni Zulaiha

This work is licensed under a Creative Commons Attribution-ShareAlike 4.0 International License.

Diterima: 14 Februari 2020; Direvisi: 23 April 2020; Disetujui: 24 April 2020 
Khazanah Pendidikan, Vol. 2 No. 1: 12-21

Penerapan Metodologi Penafsiran Al-Qur'an Dalam Dakwah

Abdul Rauf Bin Rimi dan Eni Zulaiha

Kesemua kitab samawi yang telah diturunkan sehingga ke Nabi Muhammad saw yaitu Al-Qur'an ianya mempunyai satu tujuan yang sama adalah menyuruh kepada mendekatkan diri kepada Allah serta mengimaminya dengan sepenuh hati. Dan juga mengajak untuk berbuat kebaikan dan memberikan nesahat yang baik serta jangan mensyirikkan Allah swt. Pada dasarnya kesemua kitab yang terdahulu mempunyai tujuan yang sama yaitu membawa kearah kebenaran dalam menegakkan agama. Ini telah dijelaskan di dalam Al-Qur'an dengan firman Allah swt dalam surat Asy-Syura 42;1.

Adapun terdapat kitab yang terdahulu yang diturun sebelum Nabi saw yang mana kitab tersebut tidak lagi releven yang untuk digunakan. Ini disebabkan telah berlaku campur aduk, di ubah dan di ganti yang terdapat di dalam kitab tersebut dari tangan manusia. Baik dari sudut teka, konteks, isi, dan lain sebagainya. Kerana mereka yang mengubah isi kitab tersebut mempunyai kepentingan masing-masing.

Kitab terakhir yang diturunkan tidak pernah datang dengan membawa kebatilan melainkan membawa risalah kebenaran kepada manusia, baik dahulu maupun sekarang. Hal ini dijelaskan oleh berbagai ayat di dalamnya dengan jelas dan gambling. Seperti apa yang dikemukakan dalam surah alAn'am 6:91 tentang bangsa yahudi

Fungsi Al- Qur'an tidak hanya membawa kebenaran akan tetapi ia juga merupakan pembawa cahaya, penyembuh segala penyakit, dan merupakan pembeda antara kitab yang dahulu. Saat orang berkata berlandaskan Al-Qur'an, di saat orang menggamalkan Al-Qur'an dalam hidupnya dia akan mendapat pahala, di saat datangnya untuk mengadili sesuatu perkata, dia tidak pernah membelakanngi Al-Qur'an, dan siapa yang mengajak orang kearah kebaikan maka dia akan diberikan petunjuk atau jalan yang benar (Jafar \& Amrullah, 2018).

Turunnya Al-Qur'an secara beransur-ansur dengan membawa syariat berdasarkan suatu peristiwa atau sebab berlakunya kejadian pada waktu itu. ia bertujuan supaya dapat dipahami dan dimengerti dengan apa yang disampaikan. Adapun beberapa kaedah pemahaman ini adakalanya ia memerlukan penilaian dalam penyelerasan antara penceritaan masa lalu dan juga penceritaan masalah masa kini. Untuk itu, ia haruslah memperlihatkan apa yang umum dan apa yang khusus terhadap sesautu bentuk dan mutlak muqayyad yakni sesuatu yang tidak ada kaitan dengan sifatnya. Ataupun juga, berlaku ayat dan perkataan yang sulit dimengertikan dan terkadang mempunyai makna-makna tersirat yang tertentu. Adapun untuk menerangkan dan menyampaikan tentang apa yang isi kandungan yang terdapat pada isi ayat serta untuk mengetahi beberapa aspek yang penting dalam kandungan, maka kehadiran tafsir diperlukan untuk menjelaskan apa yang dinyatakan (Murtadha \& Mutawali, 2017).

Terdapat ramai mufassir yang telah cuba untuk menjelaskan dan menerangkan isi kandungan dengan memberikan pemadanan kata sesuai, menerangkan istilah makna sepadan, membahas dan mengkaterogrikan hokum dalam kitabullah dan beberapa aspek yang lain dalam menafsirkan sepertinya asbab nuzul yakni sebab turunnya ayat tertentu, ayat yang dipadamkan dengan ayat yang lain. Diskusi, ayat penegasan yaitu sumpah, dan beberapa yang lain yang berkaitan dalam menafsirkan.

Terdapat juga berbagai modus operandi dalam bagian penafsiran Al-Qur'an. Berkembangnya pembagian dalam tafsir bermula dari sebuah dari zaman dahulu hinggalah pada masa sekarang. Ianya terbagi kepada empat modus operandi yaitu ijmali, muqarin, tahlili dan maudhui'(Nawawi, 2017).

Keempat-empat metode tersebut mempunyai masing-masing karekteristik dan juga langkahlangkah tersebut yang dari semua sudut berbeda dari aspek penerapan. Oleh itu penulis akan membahaskan tentang empat modus ini dengan lebih terperinci dengan judul dalam karya ini yang berjudul Penerapan Metodologi Penafsiran Al-Qur'an Dalam Dakwah 


\section{METODE PENELITIAN}

Dalam meotdologi yang digunakan dalam pembahasan ini lebih kepada kajian kepustakaan (library research) (Sadiah, 2015). Yang mana ia melihat karakter bagi seorang dai mau pun mufasir dalam menerapkan metodologi tafsir ke dalam dakwah. Pembahasan ini memfokuskan tentang baik dari dai maupun mufassir itu membawa atau menerangkan kepada masyarakat kaedah tafsir yang benar supaya inti dari pemaknaan ayat Al-Qur'an tersebut tidak di salah artikan.

Adapun pengertian metode ini adalah bersifat umum dan ia juga dapat digunakan dalam pelbagai objek (Sugiyono, 2013). Dalam pengajian ini yang mana ia melibatkan dengan penafsiran Al-Qur'an, ia bertujuan supaya gerak kerja dalam menafsirkan Al-Qur'an tersebut dijalankan dengan teratur dan juga terjaga. Ia juga tidak hanya berkaitan dengan faktor luaran akan tetapi ia melibatkan dengan faktor dalaman yang ilmu tentang Al-Qur'an tersebut haruslah didalami kerana objek yang akan diteliti dalam penafsiran adalah Al-Qur'an yang juga merupakan kalam Allah.

Dalam pengartian makna tafsir ini bisa ditemukan selain daripada Al-Qur'an yang mana ia ditemui di dalam atsar. Terdapat sebagian besar dari para golongan ilmuan dari kalangan para sahabat baginda yang mana ia sangat teliti dan peka dalam suatu persoalan yang mana persoalan tersebut melibatkan tentang penfsiran yang tiada ilmu. Dalam riwayat daripada Mujahid dan juga Qatadah serta beberapa yang lain dari kalangan mereka menyatakan bahwa di saat mereka menafsirkan kitab suci tersebut yaitu AlQur'an. Mereka tidak memperkirakan sama sekali terhadap apa yang mereka lakukan. Ini karena mereka menyatakan tersebut dengan pandagan dari sudut mereka sendiri. (HR al-Tarmidzi)

Dari sudut bahasa, tafsir merupakan sesuatu perkara yang memerlukan penjelasan, menunjukkan dan juga memperincikan. Pada mulanya kata tafsir tersebut di ambil dari kata dari al-fasr yang membawa maksud membuka dengan sesuatu dari perkara yang tertutup. Dengan makna yang lebih umum adalah memberikan penerangan atau penjelasan dari perkara yang tidak diketahui atau tidak diperjelaskan.

Setelah mengetahui pemaknaan dari kata tafsir itu sendiri, supaya lebih jelas dan tidak menyalahartikan dari sudut bahasa yang akan ditafsirkan, adalah lebih sesuai dengan kata masdar dalam kaedah dasar dalam bahsa arab

Diambil dari pernyataan dari ar-raghib al asfahani yang mana ia menjelaskan bahwa kata al-fasr itu dan juga alsafr itu mempunyai kerakter dan juga kemiripan yang dekat dari sudut makna. Adapaun al fasr diguna pakai dalam memperjelaskan dari sudut konsep yang mana ia memerlukan daya pikir. Manakala dari kata alsafr itu menjelaskan dalam membuktikan suatu perkara yang boleh diketahui oleh pancaindera. Secara mudahnya adalah al-fasr itu masih di alam ide manakala alsafr itu adalah sesautu yang telah dikembangkan deng an bisa diterjemahkan dengan bentuk yang nyata.

Berpindah kepada topik utama yang yaitu pengetahuan tentang ilmu metode tafsir. Setelah mengetahui makna tafsir itu sendiri adapun dalam metodologi ini melibatkan cara untuk menjelaskan apa yang terkandung di dalam Al-Qur'an. Adapaun tentang metodologi ini meunjukkan ilmu tentang metode yang akan diguna pakai dalam menafsirkan Al-Qur'an. Terdapat beberapa term-term yang akan dijelaskan dalam pembahasan ini.

Seterusnya dengan kata dakwah. Kata dakwah ini dengan arti yang ringkas dan mudah difahami yaitu, mengajak, membawa kearah kebaikan, menyampaikan sesautu yang benar dan juga memberi nasehat kepada mad'u yakni masyarakat.

Adapun menurut syeikh Dr. Yusuf al-Qardhawi, beliau menjelaskan bahwa dakwah tersebutadalah suatu usaha yang dilakukan untuk mengajak orang kearah agama Islam dan juga mengikut pentunjuk dari Allah dalam menegakkan syariat dan kebenaran. Selain itu juga beliau juga memperjelaskan bahwa supaya masyarakat tersebut mengEsakan Allah swt dengan melakukan ibadah dan juga perkara kebaikan 
Khazanah Pendidikan, Vol. 2 No. 1: 12-21

Penerapan Metodologi Penafsiran Al-Qur'an Dalam Dakwah

Abdul Rauf Bin Rimi dan Eni Zulaiha

dalam khidupan. Ia bertujuan untuk mengikat diri daripada melakukan segala perbuatan yang mungkar dan juga bercanggah dengan syariat. Selain itu, beliau juga mengajak supaya melakukan kebaikan dan juga mencegah atau melarang daripada melaku perbuatan yang mungkar atau perkara yang batil.

Secara kesimpulan dakwah itu adalah sesautu perbuatan yang dilakukan oleh semua orang Islam yang mana ia mengajak kearah kebaikan dengan melarang melakukan perbuatan yang batil. Apabila dikaitkan dengan tafsir maupun metodenya dalam dakwah ia secara tidak langsung adalah menyampaikan perkara yang benar yang terkait dengan Al-Quran dengan memberikan pengertia yang jelas supaya boleh di fahami oleh semua umat Islam. Dengan kaedah penyampaian nas-nas Al-Qur'an dengan menafsirkan dengan penuh bijaksana dan sesuai dengan zaman sekarang.

Adapun metode yang digunakan dalam pembahasan ini lebih kepada teori dakwah yang mana ia adalah tentang teori stimulus respon (Prastowo, 2011). Dalam teori ini pendakwah memberi dengam memberikan suatu pertanyaan yang mana ia melibat audien atau sasaran dakwah. Selain itu juga stimulus ini digunakan untuk mencapai sesuatu hasil daripada penyampaian dakwah yang telah dilakukan. Teori ini tergantung dengan kedua pihak penyampai dan juga penerima yang mana ia hendak melihat bagaimana reaksi dalam situasi tersebut.

\section{HASIL DAN PEMBAHASAN}

Dalam metode tafsir terdapat empat metode yang telah dijelaskan dalam menafsirkan Al-Qur'an. Yang mana ia mempunyai masing-masing karekter dalam menafsirkan ayat Al-Qur'an, antaranya adalah metode ijmali, tahlily, muqaran dan juga maudhui. Adapun penjelasan yang dilakukan adalah berikut:

Pada saat Al-Qur'an tersebut ditafsirkan oleh Baginda dan juga para sahabat secara umum dan ia tidak memperdetailkan apa yang ditafsirkan dengan ayat-ayat tertentu. Kerana itu terjadi apabila terdapat tafsir yang telah dilakukan oleh mereka pada ketika itu sulit ditemukan kerana ianya bersifat umum. Perkembangan metode ini berkembang sehingga pada ketika itu di saat as-suyuthi menetapkan bahwa tafsir ini dibagikan dalam dua bentuk yaitu tafsir bil ma'tshur dan juga tafsir bil ra'yi. Dan kemudian ia berkembang dengan lebih luas dalam beberapa bidang dalam cabang metodologi tafsir itu sendiri.

Terkait dengan metode penafsiran Al-Qur'an, ada beberapa jenis metode yang biasa digunakan oleh ulama' tafsir. Antaranya adalah :

\section{Metode Tahlili}

Untuk yang pertama ini menerangkan isi dari Al-Qur'an dari sudut yang berbeda yang mana ia menerangkan kesesuaian dengan pandangan, keinginan para kalangan mufasir yang menyampaikan berdasarkan urutan ayat yang terkandung di dalam Al-Qur'an (Amin, 2017).

Kebiasaanya ia merangkumi beberapa aspek baik dari sudut pemaknaan yang umum dari katanya, kolerasi ayat dengan yang sebelumnya, sebab turunya ayat jika terdapat, arti kata yang umum, hokum yang dapat diangkat, dan ayat tersebut tidak jarang dan sering dijelaskan dalam beberapa pendapat berlainan mazhab. Terkadang,ada dikalangan mereka memasukkan penjelasan dari sudut keindahan dalam membaca ayat, perkataan yang dijelaskan dalam tafsir dan juga beberapa susunan kata di dalamnya.

Adapun dalam penjelasan metode ini, yang mana ia mempunyai pelbagai bentuk yang mana ia harus difokus dalam penafsirannya. Yang mana ia merangkumi aspek yang bersifat bahsa, syariah, bentuk yang kordial dan budaya, pola pikir atau ideology dan juga kebijaksanaan dan juga lain sebaginya yang mana ia menyangkut tentang penafsiran. Kerana ia memiliki masing-masing fungsi dan juga metode yang berbeda dalam menafsirkan ayat Al-Qur'an. 
Sesuatu metode baik kontemporer mau pun klasik pasti akan kekurangan dan juga kelemahan dalam metode ini. Di saat ketika mana para mufassir mengeluarkan makna-makna dari Al-Qur'an dengan kurangnya cabang-cabang ilmu metode yang mereka tersebut harus memhalusi dengan cermat sehinggakan ia mengakibatkan keanehan dalam makna yang disampaikan.seperti yang diketahui apa pun bentuk yang disampaikan ianya tidak akan pernah selesai dan lengkap kerana akan sentiasa metode, corak, bentuk yang baru dalam menjelaskan sesautu ayat tersebut.

Faktor ini berlaku disaat para kalangan mufassir tersebut sering memberikan pandangan terhadap sesuatu ayat yang sedang dibahaskan. Yang mana ayat itu juga tidak terkait dengan ayat yang lain yaitu tidak terikat dengan makna ayat. Ini terdapat dalam kitab suci kalam Allah yang mana ia menjelaskan tentang judi dan khamar dalam surat Al-baqarah ayat 219 bahwa keduanya adalah dosa besar, justeru lebih banyak mudarat daripada manfaat.

Dalam penjelasan yang dijelaskan oleh para kalangan muffasir yang meneliti dengan metode ini setidaknya memberikan tidak bentuk pertanyaan utama, yang mana ia merangkumi aspek judi, arak dan juga pemaknaan tentang nafqah. Ketiga-tiga persoalan ini tidak pernah selesai kerana sebagian daripada ayat-ayat tersebut tidak dapat di tanggapi kerana terikat dengan ayat yang lain. sebagai contoh dalam surat al maidah ayat 90 menyatakan bahwa perkara tersebut merupakan perbuatan syaitan yang mana ianya wajib di jauhi.

Secara umumnya bahwa para mufassir tersebut dapat memberikan secara total tentang pemaknaan ayat di dalam Al-Qur'an setelah ditafsirnya. Tetapi khususnya adalah mereka tidak dapat memberikan penjelasan menyeluruh terhadap uraian dari kalam Allah tersebut. Kerana terbatasnya ilmu yang dimiliki.

\section{Metode Ijmali (global)}

Dari sudut bahwa, kata ijmali itu adalah suatu rangkuman atau intisari. Dalam bentuk metode ini lebih kearah dalam menghidangkan ayat dan kandungan dalam Al-Qur'an dalam penjelasan yang luas dan ia tidak memperincikan sesautu. Dalam pembahasan ini, ianya hanya merangkupi beberapa bagian dengan menggunakan bahasa yang mudah ringkas dan sebagainya. Adapun beberapa kitab tafsir yang mana menjelaskan dengan mengutamakan makna dari kata, sebab turunnya ayat dan juga beberapa penjelasan mengenaai ayat tersebut (Murtadha \& Mutawali, 2017).

Demikian yang telah dijelaskan berkenaan dengan metode ini yang mana ia merupakan pengajian yang mudah, practical dalam menerima pesan yang terdapat di dalam Al-Qur'an. Jadi dengan metode ini, mudah dilihat dari sudut pesan dan makna yang ingin disampaikan kerna metode ini di pandang sederhana daripada metode-metode tafsir yang lainnya.

Dari sis yang lainnya pula, terdapat kekurangan yang menyebabkan metode ini mudah yaitu ianya dari sifat metode itu sendiri yang mana ia tidak spesifik dan pengkajian tersebut keliatannya amat dangkal, corak pikir yang agak sedikit pengetahuannya dan juga ianya tidak bersifat menyeluruh dari setiap sudut.

\section{Metode Muqaran}

Bentuk dalam pemaparan metode ini merangkumi beberapa aspek yaitu::

Adapun beberapa ayat yang terkandung Al-Qur'an yang mana ianya berbeda pengarang mengenai beberapa ayat tersebut, akan tetapi apa yang dibahaskan itu merupakan suatu lontaran persoalan yang sama.

Kandungan bagian yang kedua adalah apabila beberapa ayat Al-Qur'an itu tersebut berbeda dengan isi dalam hadith Nabi saw. Adapun setelah ayat Al-Qur'an tersebut dinyatakan akan tetapi berbeda dengan hadith yang telah dinyata, tidak bermakan ianya bercanggah dengan Al-Qur'an akan tetapi para kalangan 
Khazanah Pendidikan, Vol. 2 No. 1: 12-21

Penerapan Metodologi Penafsiran Al-Qur'an Dalam Dakwah

Abdul Rauf Bin Rimi dan Eni Zulaiha

mufassir itu memerlukan ilmu yang cukup dan bijaksana dalam menafsirkan ayat Al-Qur'an tersebut sebagaimana yang contoh ayat diatas dan dijawab juga dengan hadith adalah:

Apabila berlaku perbedaan pendapat ulama yang mana ia terkait dengan penafsiran yang sama. Ia adalah suatu pembahasan bentuk yang mana ia melibatkan perbandingan satu ayat dengan ayat yang lain dari kalangan mufassir dengan mufasir yang lain dalam menjelaskan suatu perbahasan. Dalam satu masa itu juga melakukan perbandingan terhadap penafsiran tersebut. Perbandingan yang dilakukan itu tidak hanya sekadar menyampaikan pembahasan akan tetapi dengan menyatakan tanggapan dan juga komen yang mereka hendak utarakan dalam mencoba untuk menyamakan atau sebaliknya suatu penafsiran. Ini bertujuan supaya dalam pembahasan tersebut di kalangan mereka dapat mencari titik lemah dan titik kuat dalam sebuah penafsiran tersebut (Wahid, 2018).

\section{Metode Maudhui}

Dalam metode yang terakhir adalah metode yang mengarahkan kepada beberapa aspek dengan menentukan beberapa tema yang telah dinyatakan. Dalam ini juga, metode ini mencuba untuk mengeluarkan ayat-ayat kemudian di kumpulkan kemudian diperbahaskannya, dianalisa dan kemudiannya memahami per ayat yang telah dikumpulkan. Apabila selasai, dengan memasukkan beberapa uraian hadith yang berkaitan dengan ayat yang dikumpulkan dan akhirnya membuat kesimpulan yang mana isinya adalah suatu pandangan seluruhnya yang terkait dengan judul pembahasan yang dikemukakan (Makhfud, 2016).

Dalam pembahasan ini juga metode ini memberikan beberapa langkah yang digunakan dalam metode ini. Yang mana ia adalah :

1. Mengambil dan memfokuskan tem yang akan dibahaskan

2. Mencari dan mengumpulkan semua ayat Al-Qur'an yang berkaitan tema yang dibahaskan

3. Meneliti dan mengkaji per ayat yang telah dikumpulkan dan dipilah ayat tersebut sekiranya ada kaitan dengan tema yang dibahaskan, lalu memperlihatkan sebab penurunan ayat tersebut.

4. Mengatur rentetan ayat Al-Qur'an dengan masa turunyaa, dalam langkah ini lebih memfokus apabila ia terkait dengan permasalahan hokum, urutan dalam penceritaan sewaktu berlakunya sesuatu perkara dari awal penceritaan hingga akhirnya penceritaan tersebut.

5. Mengetahui dan mengambil hubungan di antara ayat yang dibahaskan dengan surat di dalamnya yang terkait.

6. Merangka suatu pembahasan yang sistematis atau merangka outline dalam sautu pembahasan

7. Meletakkan dan memasukkan dengan hadith dan juga penjelasan dari riwayat para sahabat dan juga lainya yang mana hadith tersebut mempunyai kaitan atau sesuai dengan tema yang di bahaskan. Ianya untuk melengkapkan tema yang diatur dalam metode ini.

8. Kemudian apabila selasai langkah-langkah yang telah dilakukan tadi. Jadi terdapat sebuah gambaran terhadapa ayat yang dibahas. Lalu lakukan dengan menyeleksi ayat tersebut kepada beberapa bagian yang mana yang umum dan khusus. Sehinggalah menemui sautu kesimpulan yang terdapat jawapan hasil melakukan itu.

Setelah mengetahui pembahasa tentang tafisr, metodologi tafsir dan sebagainya, lalu kebagian poin yang kedua penting yaitu dakwah. Seperti yang kita yakni orang Islam yang sudah sedia maklum yang mana dakwah pada umumnya ianya merupakan suatu ajakan yang membawa kepada kearah kebaikan dan juga cenderung untuk menjauhi daripada berlakunya kemungkaran. Dakwah ini juga membawa arti 
cakupan yang luas dan juga makna yang mendalam bagi orang yang tertentu disamping menyebarkan tema Islami kepada mad'u (sasaran dakwah).

Adapun bentuk dakwah yang telah diketahui di dalam ayat Al-Qur'an bil hikmah, mengeluarkan kata-kata yang baik dan sopan, dan mujadalah dikalangan kamu dengan baik. Dalam untuk menarik perhatian kepada mad'u, tiga perkara pokok ini harus ada dalam diri pendakwah tersebut. Supaya mad'u itu mendengar apa yang disampaikan dan juga menggelakan daripada berlakunya kesalahfahaman dalam isi atau pesan yang di sampaikan.

Adapun dakwah yang disampaikan itu hendaklah corak yang mana bisa beradpatasi dengan keadaan sasaran dakwah. Ini kerana tidak semua dakwah itu sama baik dari sudut kondisi, prasarana, prilaku dan lain. Jadi pendakwah iu haruslah bijaksana dalam memgambil kesempatan yang sebaik mungkin dalam mencari titik temu di antara pendakwah dan sasaran dakwah serta isi pesan dakwah tersebut.

Terdapat beberapa pengertian dakwah menurut para ulama yang mana ianya adalah:

1. Menurut daripada Muhammad Al Ghazali menyatakan bahwa adapun dakwah tersebut adalah sautu aturcara yang mana isinya dalam acara tersebut lengkap. Ini kerana setiap aturan dalam acara tersebut merangkumi setiap tujuan dan apa yang hendak dicapai dalam mencari panduan dalam hidup mereka.

2. Daripada Dr Yusuf Al-Qardawi menjelaskan bahwa, beliau menerangkan dengan memberikan pemaknaan dakwah itu yang mana ia merupakan satu usaha untuk membawa orang lain kepada agama Islam. Dengan memenuhi semua aspek yang di tuntut dalam ajaran Islam yang mana ianya melibatkan taat kepada pencipta. Maksudnya adalah Dia (Allah) tempat bagi orang Islam mengadu pertolongan dan juga bersyukur. Dakwah ini pula yang beliau nyatakan adalah mengajak untuk melakukan dan menyebaran perkara kebaikan dan juga melarang serta menjauhi perkara yang maksiat dan juga perkara yang mungkar. Dia juga menyaran untuk berjihad di jalan Allah. Menurut penulis dalam konteks jihad itu adalah pemaknaan yang luas dan tidak hanya disempitkan dengan berperang melawan kejahatan dan lain sebagainya.

3. Dalam kitab yang dikarang oleh Adam Abdullah Al-Auri yaitu tarikh al-dakwah al-islamiyat baina al-amas ila al yaum, ia menjelaskan bahwa dakwah tersebut adalah membawa pola pikir dan pandangan manusia yang bersifat duniawi kepada pola pikir dan pandangan yang berdasarkan aqidah.

4. Dakwah yang dimaksudkan oleh Dr Abu Al-Majd Al-Sayyid Nawfal mengartikan bahwa dakwah tersebut adalah satu kelompok yang mana mempunyai kemampuan dalam menyampaikan pesan dan nasehat yang baik serta tunjuk ajar kepada mereka. selain itu juga ia untuk membawa mereka itu kepada Islam dan menjauhkan diri mereka dari perkara yang boleh menyekutukan Allah dengan pelbagai bentuk dan cara.

5. Menurut Dr Ra'uf Shalabi menjelaskan bahwa dakwah islamiyah itu merupakan sautu gerakan yang membawa kepada suatu perubahan dalam diri masyarakat dari belenggu kekufuran dan kegelapan dibawa ke keadaan yang nurr Islam itu sendiri yaitu keimanan.

Setelah mengetahui beberapa penjelasan dan penerangan tentang makna dakwah itu dari golongan ulama, jadi bisa disimpulkan bahwa dakwah tersebut merupakan usaha yang dilakukan baik dari perorangnya maupun perkelompok yang mana ia bertujuan kearah satu yaitu membawa manusia itu mencapai redha Allah swt dengan melakukan wajib yang diperintahkan dan juga perkara yang baik dan diamalkan oleh manusia. 
Khazanah Pendidikan, Vol. 2 No. 1: 12-21

Penerapan Metodologi Penafsiran Al-Qur'an Dalam Dakwah

Abdul Rauf Bin Rimi dan Eni Zulaiha

Dalam dakwah ini terdapat beberapa unsur yang boleh ada disaat proses penyampaian yang ia adalah :

1. Pendakwah- orang yang menyampaikan pesan atau nasehat

2. Sasaran dakwah- kepada siapa yang kita ingin berdakwah baik perorang atau perkelompok

3. Materi/ bahan dakwah- bahan yang digunakan harus sesuai dan tidak berlaku khilaf semasa menyampaikan dakwah

4. Media yang digunakan untuk berdakwah-perantaraan yang dilakukan semasa berdakwah

5. Corak dakwah- metode yang sesuai yang digunakan oleh pendakwah.

6. Efek dakwah- kesannya kepada sasaran dakwah yang mana ia meliput kesimpulan dalam dakwah yang disampaikan apakah mencapai tujuan atau sebaliknya.

Selain itu juga metode yang digunakan dalam menyampaikan dakwah yang mana ia terdiri tiga metode yang disebutkan didalam Al-Qur'an dalam surat an-Nahl ayat 125 ialah bil hikmah, mauizah hasanah, bermujadalah.

Di dalam pecahan mujadalah itu terbagi kepada enam bagi bentuk yaitu, ceramah, soal jawab, berdikusi, tatap muka, contoh yang baik, membuat perjanjian dalam sesuatu perkara dan juga dalam membantu golongan yang susah.

Pada dasarnya ianya bukan suatu perkara yang sukar dan berat. Akan tetapi yang menjadikan ia susah adalah bagaimana cara dan apa yang perlu dilakukan oleh mereka untuk menyampaikan dakwah. Akan tetapi disebabkan mereka pada umumnya meletakkan bahwa dakwah tersebut hanyalah dilaku oleh para golongan pendakwah ustaz dan lain saja. Kerana mereka lupa dakwah ini adalah wajib dilakukan oleh semua orang Islam yang mukallaf. Bagi penulis cukuplah bagi mereka untuk memberikan pesan yang baik nasehat yang boleh diikut mengikut kemampuan dan batas ilmu yang mereka miliki.

Adapun dalam penerapan metodologi penafsiran Al-Quran dalam dakwah yang mana yang menyangkup dalam isi pesan dakwah. Dalam isi pesan tersebut adalah apa yang akan di sampaikan oleh penceramah kepada mad'u yaitu sasaran dakwah.

Dalam untuk mengetahui karakter baik dari sudut perbandingan di antara seorang muffasir dan juga dakwah bisa di simpulkan adalah :

Seorang mufassir tersebut haruslah memiliki ilmu yang mana ia adalah:

1. Dia mengetahui dan memahami istilah bahasa arab dan cabang di dalamnya yang digunakan.

2. Dia juga harus lah mengetahui penyusunan kalimat dari sudut maknya yang dikemukakan

3. Dia harus tahu dalam membedakan pemaknaan dari sifatnya dari ayat atau perkataan tersebut jelas atau sebaliknya. Dan ia disebutkan sebagai ilmu bayan

4. Dia juga harus mengetahui kalimat-kalimat yang berunsurkan keindahan dari dalam AlQur'an disebutkan sebagai ilmu badi'

5. Dari sudut tafsir ilmu qira'at itu merujuk kepada makna yang berbeda dalam masa yang sama ianya membantu menetapkan makna tersebut. Ianya disebutkan sebagai ilmu qiraat.

6. Ilmu yang ditujukan kepada lafaz yang menunjukkan mustahil dinisbahkan kepada Zat yang maha Eza yaitu ilmu ushul addin

7. Ushul fiqh adalah suatu cara dalam mengistinbat hokum yang terdapat di dalam AlQUu'ran

8. Mengetahui isi ayat yang digunakan dalam penjelasan ayat disebutkan sebagai asbab nuzul

9. Mengetahui tentang suatu hokum yang di batalkan dipanggil ialah nasakh mansukh 
10. Arif dalam fiqh

11. Mengetahui setiap hadith yang dinisbatkan kepada nabi dalam penafsiran.

12. Ilmu mauhibbah ini adalah suatu ilmu yang diberikan Allah kepada manusia sehingga bisa menjadi seorang mufassir

Menurut prof dr. hamka menjelaskan beberapa perkara yang mana ianya persyaratan untuk menjadi seorang pendakwah yang mana ia perlu diperhatikan yaitu:

1. Seseorang harus memiliki sikap muhasabah diri yang tujuan dia dalam berdakwah

2. Seseorang itu harus bersifat cermat dan tidak terburu-buru dalam menjawab persoalan yang disampaikan.

3. Seorang itu hendak mempunyai sikap yang tidak mudah mengikut dan terpengaruh dan sikap yang sentiasa merendah diri apabila mendapat pujian dari masyarakat.

4. Kriteria seseorang itu harus berketerampilan yang sesuai dan kemas.

5. Seseorang itu haruslah mengetahui dan memahami yang mana sumber utama yang digunakan adalah AL-Quran dan As-sunnah. Adapun ilmu yang lain bisa dipelajari

6. Tidak menimbulkan sesautu perkara yang mengeruhkan perkara sehingga menyebabkan kebingungan kepada masyarakat.

Adapun persyaratan menjadi seorang da'I dan juga mufasir, ia sebetulnya suatu persamaan dalam menjadi seorang yang dijadikan untuk rujukan masyarakat dalam menentukan sesuatu perkara atau menjelaskan perkara. Da'I adalah adalah umum yang mana ia meliputi semua aspek Islami. Adapun yang lain adalah gelar yang difokuskan kepada yang lebih ditelitinya. Ada di kalangan mereka mufasir, fuqaha, muhadits dan lain sebagainya.

Akan tetapi perbedaan kepada da'I atau mufassir adalah dari sudut aspek yang lain. Yang mana da'I adalah seorang yang menyampaikan perkara kebaikan dan mencegah kepada kemungkaran serta kemaksiatan. Akan tetapi mufassir pula lebih kepada penjelasan dalam mengenali metode dan penafsiran di dalam Al-Qur'an supaya tidak berlaku penyelewengan dalam menafsirkan Al-Qur'an.

Jadi setelah mengetahui tentang isi, konten, syara mufassir dan juga da'I, apa yang ingin pembahas mengangkat pembahasan ini adalah dari aspek sudut penerapanya metodologi penafsiran bisa di masukkan dalam dakwah melalui kaedah penyampaian yang benar dan tepat. Ada di kalangan para da'I bisa memasukkan metodologi tersebut dan kesannya menyebabkan bentuk penyampaian dakwah itu menjadi cantik.

Seperti yang dijelaskan di atas menunjukkan da'I tersebut harus mengetahui dan memahami bagaimana proses metodologi penafsiran digunakan serta di sampaikan kepada masyarakat supaya apa isi yang terdapat di dalam Al-Qur'an bisa di fahami dan tidak salah dimengertikan oleh para da'i. Oleh itu, amat penting bagi seseorang itu mengetahui semua ilmu yang berkaitan dengan agama. Kerana mereka menjadi tempat rujukan dan panduan kepada masyarakat.

Seperti yang diketahui juga terdapat ada dari kalangan mereka itu, da'I di bidang kepakaran masing-masing. Sebagai contoh, ahli bidang dakwah, bidang perbandingan agama, bidang Qur'an dan tafsir, hadith dan juga sebagainya. Tujuan utama mereka adalah satu, menyebarkan kebenaran dan memberikan pelajaran terhadap agama, kitab dan lain sebagainya.

Melalui empat metode yang telah dijelaskan di atas, maka jelaskan dalam kaedah untuk memahami ayat Al-Qur'an yang hendak di sampaikan. Ini untuk mengelakkan kesalahfahaman dalam memahami konteks baik dari sudut isi dan makna ayat tersebut. Ia juga untuk memudah para da'I tersebut menukarkan ke dalam bahasa yang mudah di fahami kepada mad'u setelah pemaknaan dari ayat AlQur'an tersebut bisa dijelaskan. 


\section{SIMPULAN}

Secara kesimpulannya adalah metodelogi penafsiran yang digunakan di dalam Al-Qur'an adalah untuk menjelaskan apa yang terdapat di dalam Al-Qur'an dengan mudah. Ini karena Al-Qur'an itu bersifat global dan perlu di perjelaskan dengan menggunakan ilmu yang ada. Untukitu, da'I juga harus mengetahui supaya tidak berlaku kesalahfahaman dalam menjelaskan kepada masyarakat.

\section{DAFTAR PUSTAKA}

Amin, F. (2017). Metode Tafsir Tahlili: Cara Menjelaskan Al-Qur'an Dari Berbagai Segi Berdasarkan Susunan Ayat-Ayatnya. Kalam, 11(1), 235-266.

Bagir, H. (2017). Islam Tuhan Islam Manusia. Almizan.

Ghani, A. R. A. (2016). Metode Penurunan Al-Quran Dan Aspek Pemeliharaannya. Albasirahjournal, 6(1), 97-106.

Jafar, I., \& Amrullah, M. N. (2018). Bentuk-Bentuk Pesan Dakwah Dalam Kajian Al-Qur'an. Jurnal Komunikasi Islam, 8(1), 41-66.

Makhfud, M. (2016). Urgensi Tafsir Maudhui (Kajian Metodologis). Jurnal Pemikiran Keislaman, 27(1), 13-24.

Murtadha, R., \& Mutawali, M. (2017). Tafsir Ijmali Sebagai Metode Tafsir Rasulullah.

Nawawi, M. A. (2017). Metode Hermeneutika Kesadaran (Fenomenologi) Dalam Memahami Teks. Al-Burhan, 17(2), 183-204.

Prastowo, A. (2011). Memahami Metode-Metode Penelitian: Suatu Tinjauan Teoritis Dan Praktis. Yogyakarta: Ar-Ruzz Media.

Sadiah, D. (2015). Metode Penelitian Dakwah: Pengantar Kualitatif Dan Kuantitatif. Bandung: Remaja Rosdakarya.

Sugiyono. (2013). Metode Penelitian Pendidikan Pendekatan Kauntitatif, Kualitatif Dan R\&D. Bandung: Alfabeta.

Wahid, M. A. (2018). Corak Dan Metodologi Tafsir Alquran Al-Madjid An-Nur Karya Hasbi AshShiddieqy. Rausyan Fikr: Jurnal Studi Ilmu Ushuluddin Dan Filsafat, 14(2), 395-426. 